\title{
Impact of Inorganic Fertilizers on Yield and Yield Components of Linseed (Linumusitatissimum L.) at Western Ethiopia
}

\author{
Teshome Gutu ${ }^{1}$ and Alemayehu Dabasa ${ }^{2}$ \\ Bako Agricultural Research Center, P.O. Box 03, Bako West Shewa, Ethiopia
}

\begin{abstract}
The study was conducted west showa zone, Chaliya district Chobi Tulu Chori kebele and Horo Guduru Zone, Horo District Gitilo Dole Kebele during 2018 and 2019 main cropping season to identify optimum agronomic and economic threshold of NPS and Nitrogen inorganic fertilizers. The experiment consisted of two factors $(0$, $25,50,75$ and $100 \mathrm{~kg} \mathrm{ha}^{-1}$ NPS rates) and (0,23, 46 and $69 \mathrm{~kg} \mathrm{ha}^{-1}$ Nitrogen rates). A total of 20 treatments were laid out in Randomized Complete Block Design with three replications in $5 \times 4$ factorial arrangement. The results indicated that primary branch, capsule per plant and yield of linseed were significantly influenced by the effects of NPS and nitrogen fertilizers. The highest grain yields $\left(1400 \mathrm{~kg}\right.$ and $\left.1382 \mathrm{~kg} \mathrm{ha}^{-1}\right)$ were obtained from the application of $25 \mathrm{~kg} \mathrm{ha}^{-1} \mathrm{NPS}+69 \mathrm{~N} \mathrm{~kg} \mathrm{ha}^{-1}$ and $25 \mathrm{~kg} \mathrm{ha}^{-1} \mathrm{NPS}+46 \mathrm{~kg} \mathrm{ha}^{-1} \mathrm{~N}$ fertilizers respectively. The lowest grain yield $\left(520 \mathrm{~kg} \mathrm{ha}^{-1}\right)$ was recorded from the control treatment $\left(0 \mathrm{~kg} \mathrm{ha}^{-1} \mathrm{NPS}+0 \mathrm{~kg} \mathrm{ha}^{-1} \mathrm{~N}\right.$ fertilizers $)$. This indicates that $62.86 \%$ yield reduction was recorded as compared to the application of $25 \mathrm{~kg} \mathrm{NPS} \mathrm{ha}^{-1}+69$ $\mathrm{kg} \mathrm{N} \mathrm{ha}{ }^{-1}$ fertilizer The partial budget analysis indicated that highest net benefit (35389ETB) and acceptable marginal rate of return (2038\%) were obtained from the application of $25 \mathrm{~kg} \mathrm{NPS} \mathrm{ha}^{-1}+46 \mathrm{~kg} \mathrm{~N}^{-1}$. Therefore application of $25 \mathrm{~kg} \mathrm{NPS}+46 \mathrm{~kg} \mathrm{~N} \mathrm{ha}^{-1}$ fertilizer rates was recommended for linseed production in the study area and similar agroecology.
\end{abstract}

Keywords: Fertilizer, linseed, marginal rate of return, net benefit.

DOI: $10.7176 / \mathrm{JNSR} / 12-9-04$

Publication date:May $31^{\text {st }} 2021$

\section{INTRODUCTION}

Linseed, (Linum usitatissimum L.) ( $\mathrm{n}=15$ ), also called flax, is an important oilseed crop which belongs to the family linaceae having 14 genera and over 200 species. Linseed is one of the oldest crops known to man and it has been cultivated for both fiber and seed oil. Originated from Europe and Southern Asia (Casa et al., 1999). Linseed is thought to have been an early introduction to Ethiopia (Belayneh \& Alemayehu, 1988). The oil, which is approximately found in the rate of $35-46 \%$ in the linseed (Zuk M. et al., 2015).

Nitrogen is often the most important plant nutrients, which influences the amount of protein, protoplasm and chlorophyll formed, consequently increases cell size, leaf area and photosynthetic activity. The response of linseed to nitrogen has been well established, as has the sensitivity of crop emergence and seed yield to seedplaced nitrogen (Lafond et al., 2003). Soethe et al. (2013) also reported that nitrogen levels influenced plant height, number of capsules/plant, 1000-seed weight and seed yield ha ${ }^{-1}$. Phosphorus fertilizer is also critical for plant growth and yield of linseed. In this respect, Khan et al. (2000) reported that mean performances of linseed differed for seed and straw yields with the application of phosphorus fertilizer. Lafond et al. (2003) stated that linseed response to phosphorus fertilizer addition is highly variable, supporting the importance of maintaining medium to high soil P levels to optimize linseed yields. Kadar et al. (204) reported that P did not significantly increase the yield. You et al. (2007) concluded that to optimize crop nutrition, phosphorus must be available to the crop in adequate amounts during the growing season

Ethiopia is one the 5th major producer of linseed in the world after Canada, China, USA and India and the first producers in Africa, which is mainly produced in central highland of the nation (Delesa et al., 2010). It has a long history of cultivation by smallholder farmers and the second most important oil crops next to Noug, exclusively for its oil in the traditional agriculture of Ethiopia (Delesa et al., 2010). About 25\% of the total land allocated for oil crop production in Oromia region was covered by linseed (CSA, 2019). Even though the production area of linseed is the second largest next to Noug, its productivity is still low as compared to its potential productivity.

Optimum agronomic practice can considerably enhance the productivity of the crop. Despite its diverse use and wide production, linseed production in Ethiopia in general and in central highlands of Western Oromia is characterized by low yield and poor product quality mainly due to environmental and genetic factors as well as poor management practices such as lack of proper weed management system, poor seed and field hygiene, poor seed bed preparation, inappropriate seeding rates and methods, improper threshing ground and improper cleaning. Also little attention has been given to the fertilizer requirements of the linseed crop production in the country. Farmer use of fertilizers with linseed has been minimal to date. Even though fertilizer types applied in Ethiopia agriculture system are only urea and di-ammonium phosphate which contain only nitrogen and phosphorous. However, they may not probably satisfy the nutritional requirements of crop plants. To solve this situation the 
Ministry of Agriculture of the country has recently introduced a new fertilizer containing nitrogen, phosphorous and sulfur with the ratio of $19 \% \mathrm{~N}, 38 \% \mathrm{P} 2 \mathrm{O} 5$ and $7 \% \mathrm{~S}$ (NPS fertilizer) that substituted DAP in Ethiopian agriculture. Thus, this research was aimed;

$>$ To determinate the optimum agronomic and economic threshold of NPS and Nitrogen inorganic fertilizers.

\section{MATERIAL AND METHODES}

\section{Description of the Study Area}

The study was conducted West showa zone, Chaliya district Chobi Tulu Chori kebele and Horo Guduru Zone, Horo District Gitilo Dole Kebele during 2018 and 2019 main cropping season. Chobi Tullu Chori kebel is located between 900 '00' $\mathrm{N}$ to $9 \mathrm{o}^{\prime} 30^{\prime}{ }^{\prime} \mathrm{N}, 37 \mathrm{o} 32^{\prime} 00^{\prime}$ 'E to 37o8'00' $\mathrm{E}$ and its altitude 2450m and Gitilo Dole kebele is located between $90300^{\prime} 30^{\prime \prime} \mathrm{N}$ to $9034^{\prime} 30^{\prime \prime} \mathrm{N}, 37 \mathrm{o} 0{ }^{\prime} 30^{\prime} ' \mathrm{E}$ to $37 \mathrm{o} 8^{\prime} 00^{\prime} ' \mathrm{E}$ and its altitude $2800 \mathrm{~m}$ (Fig.1). Both locations receive a mono modal pattern of rainfall distribution that receives from May to September, which is the main rain season and the soil of the areas is reddish. Wheat, Barley, Faba bean, Field bean, Linseed and Noug are the major crops that are commonly grown in the area

\section{Figure 1. Map of the study area}

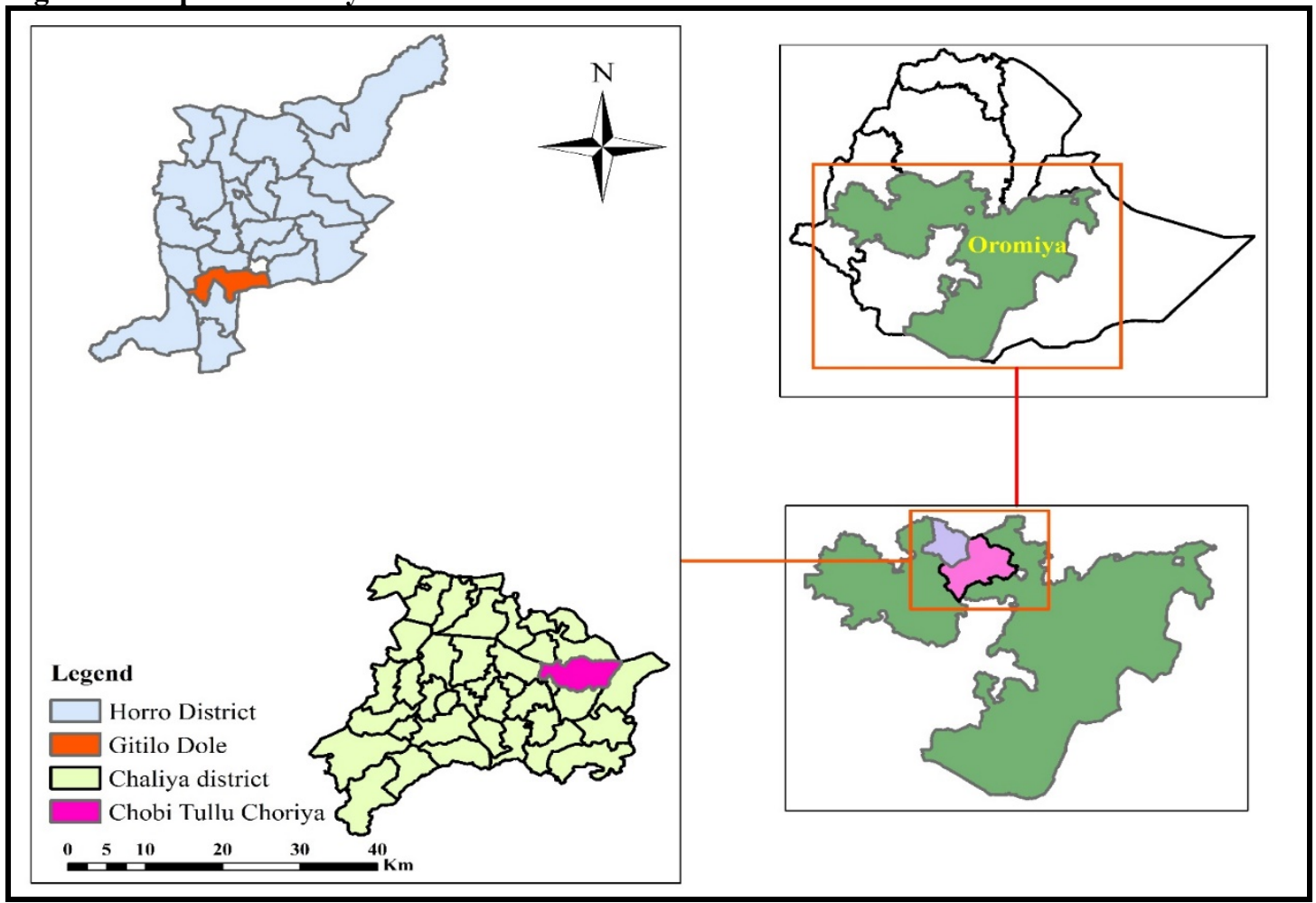

Table 1: Physico-chemical properties of experimental soil before planting

\begin{tabular}{|c|c|c|c|}
\hline \multirow[b]{2}{*}{ Soil characteristic } & \multicolumn{2}{|c|}{ Value } & \multirow[b]{2}{*}{ Description } \\
\hline & Chobi Tulu Chori & Gitilo Dole & \\
\hline Textural class & Clay loam & Clay loam & \\
\hline $\mathrm{pH}(1: 2.5 \mathrm{H} 2 \mathrm{O})$ & 5.02 & 5.07 & acidic \\
\hline Organic matter $(\%)$ & 2.74 & 1.83 & Low according to Berhanu (1980. \\
\hline Total nitrogen $(\%)$ & 0.14 & 0.09 & Poor according to Tekalign et al. (1991). \\
\hline Available phosphorous (ppm) & 8.23 & 8.58 & low According to Tekalign et al. (1991) \\
\hline
\end{tabular}

\section{Treatments and Experimental Design}

The experiment consisted of two factors $\left(0,25,50,75\right.$ and $100 \mathrm{~kg} \mathrm{ha}^{-1} \mathrm{NPS}$ rates $)$ and $\left(0,23,46\right.$ and $69 \mathrm{~kg} \mathrm{ha}^{-1}$ Nitrogen rates). A total of 20 treatments were laid out in Randomized Complete Block Design with three replications in 5x4 factorial arrangement. Recently adapted linseed variety to the study areas (Kulumsa-1) was used as a test crop. Each treatment was planted in a plot consisting of six rows of $4 \mathrm{~m}$ long with spacing of $20 \mathrm{~cm}$ between rows at a seed rate of $25 \mathrm{~kg} / \mathrm{ha}$ 


\section{Experimental Procedures and Field Managements}

The experimental plot were plowed by oxen three times and fine seed beds were prepared before planting. The seeds were sowed at spacing of $20 \mathrm{~cm}$ between rows on the experimental plot. NPS fertilizer was applied in the row as per the treatment and mixed with soil just at the time of planting while nitrogen fertilizer was applied in split, $50 \%$ during planting and the remaining $50 \%$ at vegetative stage of the crop.

\section{Soil Sampling and Analysis}

Soil samples were taken at a depth of $0-30 \mathrm{~cm}$ in a zigzag pattern randomly from the experimental field before planting from both locations. Composite samples were prepared separately for both locations to determine the physico-chemical properties of the soil of the experimental locations. The composite soil sample was air-dried, ground and sieved to pass through a $2 \mathrm{~mm}$ sieve. Total nitrogen was determined following the kjeldahl procedure as described by (Cottenie, 1980); the soil $\mathrm{pH}$ was determined by using a digital $\mathrm{pH}$ meter (Page, 1982). Organic carbon was determined following wet digestion method as described by (Walkley and Black, 1934); and the available phosphorus was measured using Olson II methods (Olsen et al., 1954)

\section{Data Collection and Measurements}

Crop Phenology and growth: Days to flowering, Days to maturity, Plant height $(\mathrm{cm})$ and Number of primary branches per plant.

Yield and Yield Components: Number of capsule per plant Biomass yield $\left(\mathrm{kg} \mathrm{ha}^{-1}\right)$ and yield $\left(\mathrm{kg} \mathrm{ha}^{-1}\right)$

Quality parameters: Oil content (\%)

Statistical Data Analysis:

Analysis of variance was carried using General Linear Model of ANOVA using SAS software. Mean separation was carried out using Least Significance Difference (LSD) test at 5\% probability level.

\section{RESULTS AND DISCUSSION \\ Crop Phenology and Growth}

The analysis of variance over locations and years showed that days to flowering and days to physiological maturity were not significantly affected by the main and interaction effects of NPS and N fertilizer rates; rather is a significantly affected due to location difference. The crop took 77 days to flower and 158 days to mature at Chobi Tulu Chori location. However, it reached flowering and maturity at 87 and 183 days, respectively at Gitilo Dole location. (Table 2). The difference could be due to altitude and temperature differences. Prolonged crop phenology at higher altitude and lower temperature. The effects of increased temperature exhibit a larger impact on grain yield than on vegetative growth because of the increased minimum temperatures. These effects are evident in an increased rate of maturity (senescence) which reduces the ability of the crop to efficiently fill the grain. Similarly, Thomas George et al. (1990) reported Days to flower initiation and physiological maturity between locations differed significantly and both phenological events were delayed considerably at the higher elevations compared to the lowest elevation.

Table 2. Main effects of NPS and N fertilizers on days to flowering and days to physiological maturity

\begin{tabular}{|c|c|c|c|c|}
\hline \multirow[t]{2}{*}{ Treatment } & \multicolumn{2}{|c|}{ Chobi Tulu Chori } & \multicolumn{2}{|c|}{ Gitilo Dole } \\
\hline & DF & $\mathrm{DM}$ & DF & $\mathrm{DM}$ \\
\hline \multicolumn{5}{|c|}{ Nitrogen fertilizer } \\
\hline 0 & 77.26 & 159.03 & 87.27 & 183.60 \\
\hline 23 & 77.13 & 158.23 & 87.13 & 182.93 \\
\hline 46 & 77.00 & 158.10 & 86.93 & 182.87 \\
\hline 69 & 76.87 & 157.43 & 86.20 & 182.73 \\
\hline LSD & NS & NS & NS & NS \\
\hline \multicolumn{5}{|c|}{ NPS fertilizer } \\
\hline 0 & 77.33 & 158.00 & 87.67 & 182.75 \\
\hline 25 & 77.17 & 157.83 & 86.25 & 182.50 \\
\hline 50 & 77.00 & 158.17 & 86.92 & 183.58 \\
\hline 75 & 77.00 & 158.50 & 86.93 & 183.25 \\
\hline 100 & 76.83 & 158.50 & 86.67 & 183.08 \\
\hline $\operatorname{LSD}(0.05)$ & NS & NS & NS & NS \\
\hline Mean & 77.00 & 158.20 & 86.88 & 183.03 \\
\hline $\mathrm{CV}(\%)$ & 0.38 & 1.02 & 1.50 & 0.67 \\
\hline
\end{tabular}

$\mathrm{DF}=$ Days to flower initiation; DM= Days to physiological maturity; LSD = Least Significant Difference $(\mathrm{P}<$ $0.05) ; \mathrm{CV}=$ Coefficient of Variation; NS =Non Significant 


\section{Plant height $(\mathbf{c m})$}

Plant height was significantly $(\mathrm{P}<0.05)$ affected by the main effect of $\mathrm{N}$ fertilizer rates but not affected by the main effects of NPS fertilizer rates and the interaction effects. The highest plant height $(86.01 \mathrm{~cm}$ and $85.99 \mathrm{~cm})$ were recorded from $69 \mathrm{~kg} \mathrm{ha}^{-1}$ and $46 \mathrm{~kg} \mathrm{~N} \mathrm{ha}^{-1}$ respectively (Table 3). As the amount of nitrogen increased from $0 \mathrm{~kg}$ to $69 \mathrm{~kg}$ the plant height also increased. The increase in plant height with increasing mineral $\mathrm{N}$ fertilizer rate up to $69 \mathrm{~kg} \mathrm{~N} \mathrm{ha}^{-1}$ could be explained by the stimulation effect for cell elongation directly after division (Dixit and Sharma, 1993) and the increase in plant height in response to application of $\mathrm{N}$ fertilizers is $\mathrm{p}$ attributed due to availability of nitrogen which enhanced more leaf area resulting in higher photo assimilates and thereby resulted in more dry matter accumulation. In agreement with this result, Geovan Soethe et al. (2013) reported that plant height was increased as the amount of urea fertilizer increased from $0 \mathrm{~kg}$ to $200 \mathrm{~kg}$. Similar to the present findings, plant height exhibited positive response to applications of high rates of $\mathrm{N}$ fertilizer (Genene $e t$ al., 2006) also Pande et al., 1970) reported that increasing levels of $\mathrm{N}$ from 0 to 22.4 and $44.8 \mathrm{~kg} \mathrm{ha}^{-1}$ significantly influenced the plant height. El-Nagdy et al. (2010) also found that plant height was 66.8, 83.7 and $105.9 \mathrm{~cm}$ by adding 25,50 and $100 \%$ of the recommended mineral $\mathrm{N}$ fertilizer rate of linseed, respectively.

Table 3. Linseed plant height and seeds per capsule as affected by NPS and N fertilizers at Chobi Tulu Chori and Gitilo Dole site during 2018 and 2019 main cropping season

\begin{tabular}{lcc}
\hline Treatment & NSPP & PH $(\mathrm{cm})$ \\
\hline Nitrogen & & \\
0 & 8.37 & $82.74 \mathrm{~b}$ \\
23 & 8.49 & $84.66 \mathrm{ab}$ \\
46 & 8.32 & $85.99 \mathrm{a}$ \\
69 & 8.40 & $86.01 \mathrm{a}$ \\
LSD & $\mathrm{NS}$ & 2.48 \\
NPS & & \\
0 & 8.37 & 84.25 \\
25 & 8.50 & 84.97 \\
50 & 8.21 & 85.20 \\
75 & 8.48 & 84.43 \\
100 & 8.40 & 85.38 \\
LSD $(0.05)$ & $\mathrm{NS}$ & $\mathrm{NS}$ \\
CV $(\%)$ & 12.86 & 8.13 \\
\hline
\end{tabular}

Means within the same column followed by the same letter or by no letters of each factor do not differ significantly at $5 \%$ probability level; LSD $=$ Least Significant Difference $(\mathrm{P}<0.05)$; $\mathrm{CV}=$ Coefficient of Variation; NS =Non Significant; $; \mathrm{NSPP}=$ Number of seed per capsule; $\mathrm{PH}=$ plant height

\section{Primary branch per plant}

The analysis of variance over locations and year showed that primary branch was highly significantly $(p<0.01)$ affected by main effect as well as their interaction effect of NPS and nitrogen fertilizer rates. The highest number of primary branches per plant (5.33.00 and 5.15) were recorded from application of $50 \mathrm{~kg} \mathrm{NPS} \mathrm{ha-1}+69 \mathrm{~kg} \mathrm{~N}^{-1}$

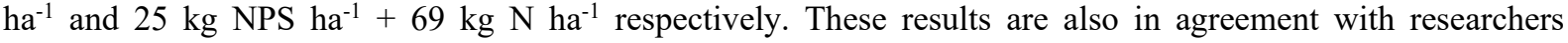
(Nayital and Singh 1984b) stated that the number of primary and secondary branches per plant increased significantly when N level increased up to $90 \mathrm{~kg} \mathrm{ha}^{-1}$. Also Sharma and Rajput (1984) stated that the growth attributes like plant height and number of primary branches per plant were significantly superior with the application of $20 \mathrm{~kg} \mathrm{~N}$ and $20 \mathrm{~kg} \mathrm{P}_{2} \mathrm{O}_{5} \mathrm{ha}^{-1}$ as compared to no fertilizer application.

Table 4. Linseed primary branch as affected by the interaction of NPS and Nitrogen fertilizer rates at Chobi Tulu Chori and Gitilo Dole site during 2018 and 2019 main cropping season

\begin{tabular}{lccccc}
\hline Nitrogen & \multicolumn{5}{c}{ NPS fertilizer } \\
\cline { 2 - 6 } fertilizer & 0 & 25 & 50 & 75 & 100 \\
\hline 0 & $2.97 \mathrm{~h}$ & $3.66 \mathrm{fg}$ & $3.54 \mathrm{~g}$ & $3.63 \mathrm{fg}$ & $3.85 \mathrm{e}-\mathrm{g}$ \\
23 & $4.25 \mathrm{c}-\mathrm{e}$ & $4.15 \mathrm{~d}-\mathrm{f}$ & $4.23 \mathrm{c}-\mathrm{e}$ & $4.26 \mathrm{c}-\mathrm{e}$ & $4.23 \mathrm{c}-\mathrm{e}$ \\
46 & $4.59 \mathrm{~cd}$ & $4.75 \mathrm{bc}$ & $4.77 \mathrm{a}-\mathrm{c}$ & $4.67 \mathrm{~b}-\mathrm{d}$ & $4.13 \mathrm{~d}-\mathrm{f}$ \\
69 & $4.78 \mathrm{a}-\mathrm{c}$ & $5.15 \mathrm{ab}$ & $5.33 \mathrm{a}$ & $4.58 \mathrm{~cd}$ & $4.28 \mathrm{c}-\mathrm{e}$ \\
LSD (0.05) & & \multicolumn{5}{c}{0.56} & & \\
CV (\%) & & 16.22 & \\
\hline
\end{tabular}

Means within the column and rows followed by the same letter do not differ significantly at 5\% probability level; LSD $=$ Least Significant Difference; $C V=$ Coefficient of Variation

Yield and yield components

The analysis of variance over locations and year showed that yield and yield components except seed per 
capsules were significantly $((\mathrm{P}<0.01)$ affected by application of $\mathrm{N}$ and NPS fertilizer. The responses of linseed to NPS fertilizer rates were very low when compared to its responses to $\mathrm{N}$ fertilizer rates but when nitrogen fertilizer was increased from $0 \mathrm{~kg}$ to $69 \mathrm{~kg} \mathrm{ha}^{-1}$ yield and yield components were significantly increased.

\section{Capsule per plant and seeds per capsule}

The combined analysis of variance over locations and years revealed that capsule per plant was highly significantly $(\mathrm{p}<0.01)$ affected by the main effect of NPS and $\mathrm{N}$ fertilizer rates and their interaction effect. The highest capsule per plant (45.16 and 42.10) was obtained from the application of $25 \mathrm{~kg} \mathrm{NPS} \mathrm{ha}^{-1}+69 \mathrm{~kg} \mathrm{~N} \mathrm{ha}^{-1}$ and $25 \mathrm{~kg} \mathrm{NPS} \mathrm{ha}^{-1}+46 \mathrm{~kg} \mathrm{~N}^{-1}$ respectively (Table 5). In contrast, number of seeds per capsule were not affected by NPS and $\mathrm{N}$ fertilizer rates (Table 3 ). The highest capsule per plant at higher $\mathrm{N}$ fertilizer could be due to the availability of nitrogen for plants is more when compared to the control treatment $(0 \mathrm{~kg} \mathrm{NPS}$ and $0 \mathrm{~kg} \mathrm{~N})$. This indicates that Nitrogen is an important factor on distribution of photosynthetic assimilates between vegetative and reproductive organs. This result was in agreement with Singh (1968) increased levels of nitrogen $\left(0,25,50\right.$ and $\left.75 \mathrm{~kg} \mathrm{ha}^{-1}\right)$ increased the number of capsules per plant. Pawar et al. (1990) reported that with increased levels of nitrogen $\left(0,15,30,45\right.$ or $\left.60 \mathrm{~kg} \mathrm{~N} \mathrm{ha}^{-1}\right)$ there was an increase in the number of capsules per plant (77.81 to 98.03).

Table 5. Capsule per plant of linseed as affected by the interaction of NPS and Nitrogen fertilizer rates at Chobi Tulu Chori and Gitilo Dole site during 2018 and 2019 main cropping season

\begin{tabular}{lccccc}
\hline Nitrogen & \multicolumn{5}{c}{ NPS fertilizer } \\
\cline { 2 - 6 } fertilizer & 0 & 25 & 50 & 75 & 100 \\
0 & $29.25 \mathrm{i}$ & $31.15 \mathrm{~g}-\mathrm{i}$ & $39.16 \mathrm{~b}-\mathrm{d}$ & $30.28 \mathrm{hi}$ & $32.31 \mathrm{~g}-\mathrm{i}$ \\
23 & $32.20 \mathrm{~g}-\mathrm{i}$ & $33.35 \mathrm{f}-\mathrm{h}$ & $37.20 \mathrm{~d}-\mathrm{f}$ & $34.73 \mathrm{e}-\mathrm{g}$ & $29.35 \mathrm{i}$ \\
46 & $38.8 \mathrm{c}-\mathrm{e}$ & $42.10 \mathrm{ab}$ & $41.66 \mathrm{a}-\mathrm{c}$ & $37.15 \mathrm{e}-\mathrm{f}$ & $32.70 \mathrm{~g}-\mathrm{i}$ \\
69 & $39.16 \mathrm{~b}-\mathrm{d}$ & $45.16 \mathrm{a}$ & $40.33 \mathrm{~b}-\mathrm{d}$ & $34.78 \mathrm{e}-\mathrm{g}$ & $3311 \mathrm{~g}-\mathrm{i}$ \\
LSD (0.05) & & & 3.91 & & \\
CV (\%) & & 13.77 & \\
\hline
\end{tabular}

Means within the column and rows followed by the same letter do not differ significantly at 5\% probability level; LSD $=$ Least Significant Difference; CV $=$ Coefficient of Variation

\section{Above ground dry biomass (quintal ha ${ }^{-1}$ )}

Above ground dry biomass was highly significantly $(\mathrm{p}<0.01)$ affected by the main effect of NPS and N fertilizer rates and their interaction effect. As the amount of nitrogen increased from zero to $69 \mathrm{~kg} \mathrm{ha}^{-1}$ the amount of above ground dry biomass also increased from 39.56 to 55.47 quintal ha ${ }^{-1}$. The highest above ground dry biomass (59'33 quintal) was obtained from the application of $25 \mathrm{~kg} \mathrm{NPS} \mathrm{ha-1}+69 \mathrm{~kg} \mathrm{~N} \mathrm{ha}^{-1}$. The increase in biomass with increased Nitrogen rates could be attributed to the fact that the enhanced availability of $\mathrm{N}$ significantly increased plant height, number of capsules per plant and to the overall vegetative growth of the plants that contributed to higher aboveground biomass. This result was in line with that of Veeresh (2003) who reported that total dry matter production per plant increased significantly from 12.0 to $16.03 \mathrm{~g}$ due to increased nitrogen application from 40 to $120 \mathrm{~kg} \mathrm{~N} \mathrm{ha}^{-1}$ on French bean.

Table 6. Aboveground dry biomass of linseed as affected by the interaction of NPS and Nitrogen fertilizer rates at Chobi Tulu Chori and Gitilo Dole site during 2018 and 2019 main cropping season

\begin{tabular}{lccccc}
\hline Nitrogen & \multicolumn{5}{c}{ NPS fertilizer } \\
\cline { 2 - 5 } fertilizer & 0 & 25 & 50 & 75 & 100 \\
\hline 0 & $39.56 \mathrm{jk}$ & $36.60 \mathrm{k}$ & $43.50 \mathrm{~g}-\mathrm{j}$ & $44.09 \mathrm{~g}-\mathrm{j}$ & $41.26 \mathrm{i}-\mathrm{k}$ \\
23 & $42.46 \mathrm{~h}-\mathrm{j}$ & $41.98 \mathrm{~h}-\mathrm{j}$ & $46.96 \mathrm{e}-\mathrm{h}$ & $44.98 \mathrm{f}-\mathrm{i}$ & $44.27 \mathrm{~g}-\mathrm{j}$ \\
46 & $50.62 \mathrm{~b}-\mathrm{e}$ & $53.82 \mathrm{~b}-\mathrm{c}$ & $47.87 \mathrm{~d}-\mathrm{g}$ & $45.75 \mathrm{e}-\mathrm{i}$ & $45.86 \mathrm{e}-\mathrm{i}$ \\
69 & $55.47 \mathrm{ab}$ & $59.33 \mathrm{a}$ & $53.15 \mathrm{~b}-\mathrm{d}$ & $52.51 \mathrm{~b}-\mathrm{d}$ & $49.93 \mathrm{c}-\mathrm{f}$ \\
LSD (0.05) & & 629 & & \\
CV (\%) & & & 14.10 & & \\
\hline
\end{tabular}

Means within the same column and rows followed by the same letter do not differ significantly at $5 \%$ probability level; LSD $=$ Least Significant Difference $(\mathrm{P}<0.05) ; \mathrm{CV}=$ Coefficient of variation

Grain yield (kg ha $\left.{ }^{-1}\right)$

The combined analysis of variance over locations and years revealed that the main effects of NPS and nitrogen fertilizers and their interaction highly significantly $(\mathrm{P} \leq 0.01)$ affected grain yield. The highest grain yield (1400 $\mathrm{kg} \mathrm{ha}^{-1}$ and $1382 \mathrm{~kg} \mathrm{ha}^{-1}$ ) were obtained from application of $25 \mathrm{~kg} \mathrm{NPS} \mathrm{ha}^{-1}+69 \mathrm{~kg} \mathrm{~N} \mathrm{ha}^{-1}$ and $25 \mathrm{~kg} \mathrm{NPS} \mathrm{ha}^{-1}+$ $46 \mathrm{~kg} \mathrm{~N} \mathrm{ha}^{-1}$ respectively. The lowest grain yield $\left(520 \mathrm{~kg} \mathrm{ha}^{-1}\right)$ was recorded from the control treatment $(0 \mathrm{~kg}$ NPS ha-1 $+0 \mathrm{~kg} \mathrm{~N} \mathrm{ha}^{-1}$ ) (Table 7). This indicates that $62.86 \%$ yield reduction was recorded as compared to the application of $25 \mathrm{~kg}$ NPS ha- ${ }^{-1}+69 \mathrm{~kg} \mathrm{~N} \mathrm{ha}^{-1}$ fertilizer. The response of grain yield to NPS fertilizer was smaller 
in magnitude than $\mathrm{N}$ fertilizer. In other words when nitrogen fertilizer was increased from $0 \mathrm{~kg} \mathrm{ha}^{-1}$ to $69 \mathrm{~kg} \mathrm{ha}^{-1}$ the yield was increased significantly but, as fertilizer rates of NPS vary from $0 \mathrm{ha}^{-1} \mathrm{~kg}$ to $100 \mathrm{~kg}^{-1}$ the observed difference was low on yield. The lower yield difference due to NPS may be due to the Mycorrhizae soil fungi that live in a symbiotic relationship with plants receive carbohydrates from the plants, and in return, the plant receives mineral nutrients from the mycorrhizae, particularly phosphate. When linseed is not fertilized with $\mathrm{P}$, yield is maintained and mycorrhizae infection is high. When linseed receives fertilizer $\mathrm{P}$, mycorrhizae infection is reduced (Grant et al., 2004). According to Thingstrup I. et al (1998) the effect of the mycorrhizal fungi increased with decreasing soil $\mathrm{P}$ levels. The increase of grain yield due to increasing mineral nitrogen fertilizer levels might be due to the role of nitrogen in protoplasm and chlorophyll formation, enhancement of meristematic activity and cell division, consequently increases cell size which improves vegetative growth, plant height and branch number and capsule number. Moreover, nitrogen encourages plants to uptake other elements activating, thereby growth of plants, consequently enhancing growth measurements and all seed yield components. Also Nitrogen is an important factor on distribution of photosynthetic assimilates between vegetative and reproductive organs. These results are also in agreement with those of several researchers (Fataneh P. K. et al. 2012) the highest grain yield (2290.79 $\mathrm{kg} \mathrm{ha}^{-1)}$ was obtained with $90 \mathrm{~kg} \mathrm{~N} \mathrm{ha}^{-1}$; Soethe et al. (2013), and Ibrahim M.H. et al (2016) the highest grain yield was obtained from the highest N fertilizer.

Table 7. Grain yield $\left(\mathrm{kg} \mathrm{ha}^{-1}\right)$ of linseed as affected by the interaction of NPS and Nitrogen fertilizer rates at Chobi Tulu Chori and Gitilo Dole site during 2018 and 2019 main cropping season

\begin{tabular}{lccccc}
\hline Nitrogen & \multicolumn{5}{c}{ NPS fertilizer } \\
\cline { 2 - 6 } fertilizer & 0 & 25 & 50 & 75 & 100 \\
0 & $520 \mathrm{j}$ & $645 \mathrm{ij}$ & $874.17 \mathrm{fgh}$ & $771.67 \mathrm{hi}$ & $775.83 \mathrm{ghi}$ \\
23 & $922.50 \mathrm{ef}$ & $930 \mathrm{ef}$ & $995 \mathrm{c}-\mathrm{f}$ & $956.67 \mathrm{def}$ & $1039.17 \mathrm{cde}$ \\
46 & $1085 \mathrm{bcd}$ & $1382 \mathrm{a}$ & $1126.67 \mathrm{bc}$ & $908.33 \mathrm{efg}$ & $1011.67 \mathrm{cde}$ \\
69 & $1097.50 \mathrm{bc}$ & $1400 \mathrm{a}$ & $1110.83 \mathrm{bc}$ & $1180 \mathrm{~b}$ & $950 \mathrm{def}$ \\
LSD $(0.05)$ & & & 135.76 & & \\
CV $(\%)$ & & & 17.14 & & \\
\hline
\end{tabular}

Means within the same column and rows followed by the same letter do not differ significantly at $5 \%$ probability level; LSD = Least Significant Difference $(\mathrm{P}<0.05)$; CV $=$ Coefficient of variation

\section{Oil content $(\%)$}

The oil content of linseed showed no significant response to NPS and Nitrogen fertilizers. Also the growing environments had no effect on oil content. However the result of laboratory tests indicated that the mean oil content was $38.56 \%$. Which is found in the standard range of linseed oil 35-46\% (Zuk M. et al., 2015).

\section{Economic evaluation}

The economic assessments were made using partial budget analysis as described by CIMMYT (1988). Economic analysis is based on the average yield of each treatment. Therefore, the net benefit estimate for 20 treatments is presented in Table 8. The highest net benefit (35389 ETB) was obtained from the application of $25 \mathrm{~kg} \mathrm{NPS} \mathrm{ha}^{-1}$ $+46 \mathrm{~kg} \mathrm{~N} \mathrm{ha}^{-1}$. The lowest net benefit (14040 ETB) was obtained from control treatment $\left(0 \mathrm{~kg} \mathrm{NPS} \mathrm{ha}{ }^{-1}+0 \mathrm{~kg}^{-1}\right.$ $\left.\mathrm{N} \mathrm{ha}^{-1}\right)$. The highest net benefit obtained from the application of $25 \mathrm{~kg} \mathrm{NPS} \mathrm{ha}{ }^{-1}+46 \mathrm{~kg} \mathrm{~N} \mathrm{ha}^{-1}$ indicated that the optimum level of fertilizer rate and net benefit increased until this fertilizer rate.

\section{Dominance analysis}

The dominant analysis showed that the net benefit of all treatments were dominated except unfertilized plot and application of $25 \mathrm{~kg} \mathrm{NPS} \mathrm{ha}^{-1}+0 \mathrm{~kg} \mathrm{~N} \mathrm{ha}{ }^{-1}, 0 \mathrm{~kg} \mathrm{NPS} \mathrm{ha} \mathrm{kg}^{-1}+23 \mathrm{~kg} \mathrm{~N} \mathrm{ha}^{-1}, 50 \mathrm{~kg} \mathrm{NPS} \mathrm{ha} \mathrm{kg}^{-1}+23 \mathrm{~kg} \mathrm{~N} \mathrm{ha}^{-1}, 0 \mathrm{~kg}$

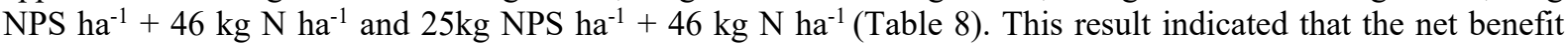
decreased as the total cost that varies increased beyond undominated treatment (application of $25 \mathrm{~kg} \mathrm{NPS} \mathrm{ha}^{-1}+$ $46 \mathrm{~N} \mathrm{~kg} \mathrm{ha}^{-1}$

\section{Marginal rate of return}

As shown in (Table 9) the result of analysis of dominant treatments indicated that for each one birr invested, it was to recover one birr plus an extra $6.50,22.01,1.91,23.79$ and 20.38 birr ha $^{-1}$ as the fertilizer application changed from unfertilized plot until optimum level of $25 \mathrm{~kg} \mathrm{NPS} \mathrm{ha}^{-1}$ and $46 \mathrm{~kg} \mathrm{~N} \mathrm{ha}{ }^{-1}$. From the control treatment that had the lowest costs to the end of the treatment which had the highest cost, that varies, the marginal rate of return obtained was above the minimum acceptable marginal rate of return. According to CIMMYT (1998) the minimum rate of return acceptable to farmers will be between $50 \%$ and $100 \%$. The best recommendation for treatments subjected to marginal rate of return is not based on the highest marginal rate of return, rather, based on the minimum acceptable marginal rate of return, and the treatment with the highest net benefit together with an acceptable rate. Therefore in this study, $50 \%$ was considered as the minimum 
acceptable rate of return for farmer's recommendation. In line with this study the application of $25 \mathrm{~kg}_{\mathrm{NPS}} \mathrm{ha}^{-1}$ and $46 \mathrm{~kg} \mathrm{~N} \mathrm{ha}^{-1}$ was the best for linseed production in the study area and similar agroecology.

Table 8. Net benefit estimation and Dominance analysis of the combined application of NPS and N fertilizers on linseed in 2018 and 2019 for both locations

\begin{tabular}{|c|c|c|c|c|c|c|c|c|c|}
\hline $\begin{array}{l}\text { Treatment } \\
(\mathrm{NPS}+\mathrm{N})\end{array}$ & $\begin{array}{c}\text { Average } \\
\text { Yield kg } \\
\mathrm{ha}^{-1}\end{array}$ & $\begin{array}{c}\text { Adjusted } \\
\text { yield }(10 \%) \\
\mathrm{kg} \mathrm{ha}^{-1}\end{array}$ & $\begin{array}{l}\text { Cost of } \\
\text { NPS ha-1 }\end{array}$ & $\begin{array}{c}\text { Cost of } N \\
\text { ha }^{-1}\end{array}$ & $\begin{array}{l}\text { Cost of labor } \\
\text { for fertilizer } \\
\text { Application } \mathrm{ha}^{-1}\end{array}$ & $\begin{array}{c}\text { Total } \\
\text { variable } \\
\text { cost }\end{array}$ & $\begin{array}{l}\text { linseed } \\
\text { Price } \\
(\mathrm{ETB} \\
\left.\mathrm{kg}^{-1}\right)\end{array}$ & $\begin{array}{l}\text { Gross } \\
\text { return } \\
(\mathrm{ETB} \\
\left.\mathrm{kg}^{-1}\right)\end{array}$ & $\begin{array}{c}\text { Net } \\
\text { benefit } \\
(\mathrm{ETB} \\
\left.\mathrm{kg}^{-1}\right)\end{array}$ \\
\hline $0 \mathrm{~kg}+0 \mathrm{~kg}$ & 5.2 & 4.68 & 0 & 0 & 0 & 0 & 30.00 & 14040 & 14040 \\
\hline $25 \mathrm{~kg}+0 \mathrm{~kg}$ & 6.45 & 5.805 & 375 & 0 & 75 & 450 & 30.00 & 17415 & 16965 \\
\hline $0 \mathrm{~kg}+23 \mathrm{~kg}$ & 9.22 & 8.298 & 0 & 700 & 75 & 775 & 30.00 & 24894 & 24119 \\
\hline $50 \mathrm{~kg}+0 \mathrm{~kg}$ & 8.74 & 7.866 & 750 & 0 & 75 & 825 & 30.00 & 23598 & $22773 \mathrm{D}$ \\
\hline $25 \mathrm{~kg}+23 \mathrm{~kg}$ & 9.3 & 8.37 & 375 & 700 & 75 & 1150 & 30.00 & 25110 & $23960 \mathrm{D}$ \\
\hline $75 \mathrm{~kg}+0 \mathrm{~kg}$ & 7.72 & 6.948 & 1125 & 0 & 75 & 1200 & 30.00 & 20844 & $19644 \mathrm{D}$ \\
\hline $50 \mathrm{~kg}+23 \mathrm{~kg}$ & 9.95 & 8.955 & 750 & 700 & 2 & 1452 & 30.00 & 26865 & 25413 \\
\hline $0 \mathrm{~kg}+46 \mathrm{~kg}$ & 10.85 & 9.765 & 0 & 1400 & 150 & 1550 & 30.00 & 29295 & 27745 \\
\hline $100 \mathrm{~kg}+0 \mathrm{~kg}$ & 7.76 & 6.984 & 1500 & 0 & 150 & 1650 & 30.00 & 20952 & $19302 \mathrm{D}$ \\
\hline $25 \mathrm{~kg}+46 \mathrm{~kg}$ & 13.82 & 12.438 & 375 & 1400 & 150 & 1925 & 30.00 & 37314 & 35389 \\
\hline $75 \mathrm{~kg}+23 \mathrm{~kg}$ & 9.57 & 8.613 & 1125 & 700 & 150 & 1975 & 30.00 & 25839 & $23864 \mathrm{D}$ \\
\hline $0 \mathrm{~kg}+69 \mathrm{~kg}$ & 10.98 & 9.882 & 0 & 2100 & 225 & 2325 & 30.00 & 29646 & $27321 \mathrm{D}$ \\
\hline $100 \mathrm{~kg}+23 \mathrm{~kg}$ & 10.39 & 9.351 & 1500 & 700 & 150 & 2350 & 30.00 & 28053 & $25703 \mathrm{D}$ \\
\hline $50 \mathrm{~kg}+46 \mathrm{~kg}$ & 11.27 & 10.143 & 750 & 1400 & 225 & 2375 & 30.00 & 30429 & $28054 \mathrm{D}$ \\
\hline $25 \mathrm{~kg}+69 \mathrm{~kg}$ & 14 & 12.6 & 375 & 2100 & 225 & 2700 & 30.00 & 37800 & $35100 \mathrm{D}$ \\
\hline $75 \mathrm{~kg}+46 \mathrm{~kg}$ & 9.08 & 8.172 & 1125 & 1400 & 225 & 2750 & 30.00 & 24516 & $21766 \mathrm{D}$ \\
\hline $50 \mathrm{~kg}+69 \mathrm{~kg}$ & 11.11 & 9.999 & 750 & 2100 & 300 & 3150 & 30.00 & 29997 & $26847 \mathrm{D}$ \\
\hline $100 \mathrm{~kg}+46 \mathrm{~kg}$ & 10.12 & 9.108 & 1500 & 1400 & 300 & 3200 & 30.00 & 27324 & $24124 \mathrm{D}$ \\
\hline $75 \mathrm{~kg}+69 \mathrm{~kg}$ & 11.8 & 10.62 & 1125 & 2100 & 300 & 3525 & 30.00 & 31860 & $28335 \mathrm{D}$ \\
\hline $100 \mathrm{~kg}+69 \mathrm{~kg}$ & 9.5 & 8.55 & 1500 & 2100 & 300 & 3900 & 30.00 & 25650 & $21750 \mathrm{D}$ \\
\hline
\end{tabular}

$\mathrm{ETB}=$ Ethiopian birr, $\mathrm{D}=$ Dominated

Table 9. Marginal rate of return of NPS and N fertilizers application on linseed in 2018 and 2019 for both locations

\begin{tabular}{cccccc}
\hline $\begin{array}{c}\text { Treatment } \\
(\mathbf{N P S}+\mathbf{N})\end{array}$ & $\begin{array}{c}\text { TVC( ETB } \\
\left.\mathbf{h a}^{\mathbf{- 1}}\right)\end{array}$ & $\begin{array}{c}\text { MC (ETB ha } \\
\mathbf{- 1})\end{array}$ & $\begin{array}{c}\text { NB (ETB ha } \\
\mathbf{- 1})\end{array}$ & $\begin{array}{c}\text { MB (ETB ha } \\
\text {-1) }\end{array}$ & MRR (\%) \\
\hline $0 \mathrm{~kg}+0 \mathrm{~kg}$ & 0.00 & & 14040 & & \\
$25 \mathrm{~kg}+0 \mathrm{~kg}$ & 450 & 450 & 16965 & 2925 & 650 \\
$0 \mathrm{~kg}+23 \mathrm{~kg}$ & 775 & 325 & 24119 & 7154 & 2201 \\
$50 \mathrm{~kg}+23 \mathrm{~kg}$ & 1452 & 677 & 25413 & 1294 & 2379 \\
$0 \mathrm{~kg}+46 \mathrm{~kg}$ & 1550 & 98 & 27745 & 2332 & 2038 \\
$25 \mathrm{~kg}+46 \mathrm{~kg}$ & 1925 & 375 & 35389 & 7644 & \\
\hline
\end{tabular}

$\mathrm{TVC}=$ Total variable cost; $\mathrm{MC}=$ marginal cost, $\mathrm{NB}=$ net benefit $\mathrm{MB}=$ marginal benefit, $\mathrm{MRR}=$ marginal ret of return, $\mathrm{ETB}=$ Ethiopian birr,

\section{CONCLUSION AND RECOMONDATION}

Linseed production in Ethiopia in general and in central highlands of Western Oromia is characterized by low yield and poor product quality mainly due to environmental and genetic factors as well as management. Also little attention has been given to the fertilizer requirements of linseed production in the country. These situations should be diverted in order to improve income, livelihood and health of farmers.

The results revealed that the response of capsule per plant and grain yield to NPS fertilizer was smaller in magnitude than $\mathrm{N}$ fertilizer. When nitrogen fertilizer was increased from $0 \mathrm{~kg} \mathrm{ha}^{-1}$ to $69 \mathrm{~kg} \mathrm{ha}^{-1}$ the capsule per plant and yield was increased significantly but, as fertilizer rates of NPS vary from $0 \mathrm{ha}^{-1} \mathrm{~kg}$ to $100 \mathrm{~kg}$ ha- 1 the observed difference was low

The highest grin yield ( $1400 \mathrm{~kg} \mathrm{ha}^{-1}$ and $1382 \mathrm{~kg} \mathrm{ha}^{-1}$ ) was obtained from the application of $25 \mathrm{~kg}$ NPS ha $1+69 \mathrm{~kg} \mathrm{~N} \mathrm{ha}^{-1}$ and $25 \mathrm{~kg} \mathrm{NPS} \mathrm{ha}^{-1}+46 \mathrm{~N} \mathrm{~kg} \mathrm{ha}^{-1}$ respectively. The lowest grain yield $\left(520 \mathrm{~kg} \mathrm{ha}^{-1}\right) \mathrm{was}^{-1}$ recorded from the control treatment $\left(0 \mathrm{~kg} \mathrm{NPS} \mathrm{ha}^{-1}+0 \mathrm{~kg} \mathrm{~N} \mathrm{ha}^{-1}\right)$. This indicates that $62.86 \%$ yield reduction was recorded as compared to the application of $25 \mathrm{~kg} \mathrm{NPS} \mathrm{ha}^{-1}+69 \mathrm{~kg} \mathrm{~N} \mathrm{ha}^{-1}$ fertilizer. When fertilizer rates of nitrogen increased from $0 \mathrm{~kg} \mathrm{ha}^{-1}$ to $69 \mathrm{~kg} \mathrm{ha}^{-1}$ the yield was increased significantly but, as fertilizer rates of NPS vary from $0 \mathrm{ha}^{-1} \mathrm{~kg}$ to $100 \mathrm{~kg} \mathrm{ha}^{-1}$ the observed difference was low on yield. The partial budget analysis indicated that highest net benefit (35389ETB) and acceptable marginal rate of return (2038\%) were obtained from the application of $25 \mathrm{~kg}$ NPS ha ${ }^{-1}+46 \mathrm{~kg} \mathrm{~N} \mathrm{ha}^{-1}$. Therefore application of $25 \mathrm{~kg} \mathrm{NPS}+46 \mathrm{~kg} \mathrm{~N} \mathrm{ha}^{-1}$ fertilizer rates was recommended for linseed production in the study area and similar agroecology. 


\section{REFERENCES}

Belayneh H, Alemayehu N (1988). Verification of improved linseed production practices on farmers' fields. In: Proc. of the Fourth Oilcrops Network shop. Njoro, Kenya, 25-29 January 1988. IDRCMR 205e IDRC, Ottawa Canda. pp.92-95.

Berhanu Debele, 1980. The physical criteria and their rating proposed for land evaluation in the highland region of Ethiopia. Land use planning and regulatory department, Ministry of Agriculture. Addis Ababa, Ethiopia.

Casa, R., G. Russell, B. Lo Cascio, and F. Rossini. 1999. Environmental effects on linseed (Linum usitatissimum L.) yield and growth of linseed at different stand densities. Europe journal of agronomy 11:267-278.

CIMMYT Economics program (1988). From agronomic data to farmer recommendations: An economics training manual. 27: CIMMYT.

Cottenie, A., 1980. Soil and plant testing as a basis for fertilizer recommendations. FAO Soil Bulletin, Rome. 38 : $61-100$.

CSA (Central Statistical Agency) 2019. Agricultural Sample Survey Report on Area and Production of Major Crops, 1: 21-22.

Delesa, A., Choferie, A. and Aka, E., 2010. Registration of Kulumsa-1 Linseed (Linumusitatissimum L.) Variety. East African Journal of Science, 4(2), pp.123-127.

Dixit S.P. and P.K. Sharma (1993). Effect of line and potassium on yield and uptake of nutrients in wheat (Triticum aestivum L.), soybean (Glycine max) and linssed (Linum usitatissinum L.) cropping sequence in an acid alfsal. Indian. Journal of Agriculture Research. 63 (6): 333 - 339.

El-nagdy GA, Nassar DMA, El-kady EA, El-Yamanee GSA (2010). Response Of Linseed Plant (Linum usitatissimum L.) To Treatments with Mineral And Bio-Fertilizers From Nitrogen And Phosphorus. Journal of American science. 6:207-217.

Fataneh Parhizkar khajani Hamid Irannezhad Majid Majidian Hussein Oraki (2012)Influence of different levels of nitrogen, phosphorus and potassium on yield and yield components of linseed seed oil (Linum usitatissimum L.) variety Lirina Journal of Medicinal Plants Research Vol. 6(6), pp. 1050-1054

Genene G, Habtamu S, Kedir N, Tilahun G, Ashinie B (2006). Response of linseed to nitrogen and phosphurus fertilizers in the highlands of Bale, South-estern Ethiopia. Sebil. Proceedings of the 12th Annual Conference of the Crop Science Society of Ethiopia 22- 24 May 2006, Addis Ababa, Ethiopia. 12:117-125.

Geovan Soethe, Armin Feiden, Doglas Bassegio, Reginaldo Ferreira Santos, Samuel Nelson, Melegari de Souza and Deonir Secco 2013. Sources and rates of nitrogen in the cultivation of linseed. African Journal of Agricultural Research Vol. 8(19) pp. 2249-2253, 23 May, 2013

Grant, D., M. Monreal, B. Irving, D. McLaren and R. Mohr. 2004. The role of P fertility and mycorrhizae in linseed production. p. 213-218. In 2004 Great Plains Soil Fertility Conference Proceedings. A.J. Schlegel, ed. March 2-3, 2004, Denver CO. Phosphate \& Potash Inst., Brookings, S.D.

Ibrahim M.H.; M.E. Kineber; A.Y. Ragab and W.F.M. A.Galoo 2016. Impact of Nitrogen fertilizer level and times of foliar spraying with potassium on yield and its components of some linseed genotypes. Journal of agriculture research kafr el-sheikh University. pp: 580-598, vol. 42(4)

Kadar I , Lukacs D, Laszlo S . Effects of nutrient supplies on the yield,quality and element uptake of oil flax . Journal of Agrokemia-es-Talajtan . 2004; 53 (1/2 ): 55 - 74

Khan, N.I. ; M. Akbar ; N. Iqbal and S. Rasul (2000). Bio-agronomic evaluation of linseed genotypes. Pakistan Journal of. Biological. Science. 3 (7): 1172-1173.

Lafond, G.P. ; C.A. Grant ; A.M. Johnston ; D.W. McAndrew and W.E. May (2003). Nitrogen and phosphorus fertilizer management of notill linseed. Better Crops, 87(1): 6-11.

Nayital, S. C. and Singh, C. M., 1984b, Effect of crop establishment methods, seed rates and nitrogen fertilization on yield, quality and economics of linseed in North-Western Himalayas. Indian Journal of Agriculture Science. 54: 659-663.

Olsen, S. R., Cole, C.V., Watanable, F.S. and Dean, L.A., 1954. Estimation of available phosphorous in soils by Extraction with Sodium Bicarbonate. U. S. Department of Agriculture, 939: 1-19.

Page,A.L., 1982. Methods of soil analysis part two. Chemical and microbilogical properties. American Society of Agronomy, 3:128-133.

Pande RC, Singh M, Agrawal SK, Khan RA (1970). Effect of different levels of irrigation, nitrogen and phosphorus on growth, yield and quality of linseed (Linum usitatissimum Linn.). Indian Journal of Agronomy. 15: 125-130

Pawar, R. D., Khade, K. K., Pawar, H. K. and Dubbal, A. R., 1990, A study on uptake of NPK by linseed varieties under different levels of nitrogen. Journal of Maharashtra Agriculture. University. 15: 339-341.

Sharma, R. S., and Rajput, V. S., 1984, Performance of seven linseed varieties with and without use of fertilizers. JNKVV Research of. Journal, 18 (1-4): 195-196.

Singh, K. D., 1968, Studies on the effect of varying levels of nitrogen and dates of sowing on yield and quality of linseed. Indian Journal of Agronomy. 13: 215-218. 
Soethe, G. ; A. Feiden ; D. Bassegio ; R.F. Santos ; S.N.M. Souza and D.Secco (2013). Sources and rates of nitrogen in the cultivation of linseed. African Journal of Agriculture research 8(19): 2249-2253.

Tekalign Mamo, Haque, L. and Aduayi, E.A., 1991. Working Document: Soil, Plant, Fertilizer, Animal Manure and Compost Analysis Manual, International Livestock center for Africa, No. B13, Addis Ababa, Ethiopia.

Thingstrup, I., Rubaek, G., Sibbesen, E. (1998). Linseed (Linum usitatissimum L.) depends on arbuscular mycorrhizal fungi for growth and P uptake at intermediate but not high soil P levels in the field. Journal of Plant and Soil 203, 37-46

Thomas George, Duane P. Bartholomew and Paul W. singleton 1990. Effect of temperature and maturity group on phenology of field grown nodulating and non nodulating soybean. Isolines .journal of Blotronics PP 4959,19

Veeresh NK (2003). Response of French bean (Phaseolus vulgaris L.) to fertilizer Levels in Northern transitional Zone of Karnataka. MSc. (Agriculture) Thesis, University Agricultural Science. Dharwad. pp. 37-79.

Walkley, A. and Black, I.A., 1934. An examination of Digestion of Degrjareff Method for Detrmining Soil Organic Matter and Proposed Modification of the Chromic Acid Titration Method. Soil Science, 37:29-38.

You, J. ; A.G. Cynthia and D.B. Loraine (2007). Growth and nutrient response of linseed and durum wheat to phosphorus and zinc fertilizers. Canadian Journal of Plant Science. 87(3): 461-470.

Zuk Magdalena, Dorota, Richter, Jan Matuła and Jan, Szopa (2015) Linseed, the multipurpose plant journal of industrial crops and products 75 165-177 